\title{
An analysis of the Factors Affecting the Functioning of the Community Radio Stations: A Review Paper
}

\author{
Neha Arya* and S.K. Kashyap \\ Agricultural Extension and Communication, College of Agriculture, \\ GBPUA\&T, Pantnagar, Uttarakhand, India \\ *Corresponding author
}

\section{Keyw ords \\ Community radio station, ICT tool, Participatory communication, Rural development, CRS functioning \\ Article Info \\ Accepted: \\ 07 February 2019 \\ Available Online: \\ 10 March 2019}

\begin{abstract}
A B S T R A C T
Community radio station is a promising ICT tool in various developing nations for the rural development. Among the other community media, community radio station has the potential to empower the grassroots people and strengthen the democracy in its operation. These radio stations work on the principle of participatory communication and are the medium of the poorest of the poor. The future of the poor and marginalised section of the society depends on how effectively and efficiently the community media are being utilized to address their specific development and informational needs. The presented paper contains a thorough review of the available literature regarding the factors affecting the functioning of the CRS. The organisational aspects, community aspects and roles played by the CRS in the community development affects the functioning of the stations in the long run. These three aspects are interrelated to each other, without taking all the three aspects, it is not possible to get the complete picture of CRS functioning. The organisational profile, programme development and broadcasting and the communicators' profile under the head of organisational aspects, are very important to study the CRS functioning from the institutional point of view. On the other hand, the community aspects like listeners' profile and community participation represents the factors related to the target population and their attitude towards the community radio station. The informational and developmental roles fulfilled by the CRS in the community are the factors facilitating the empowerment of the community. The presented criteria to assess the CRS functioning in this paper can be utilized as a framework to study the present status and challenges of the CRS functioning and can also be used to visualize the future of the operational community radio stations in the long run.
\end{abstract}

\section{Introduction}

Radio as a medium has already proven to be very effective mass medium, especially for rural areas where it informs large number of population simultaneously with relatively low cost and low network problem than other media. In addition to this advantage of radio, community radio provides need based location specific information with local participation in content development and broadcasting. Tabing (2002) defined community radio station as "one that is operated in the community, for the 
community, about the community and by the community."

Based on the theory of Participatory communication, Community radio stations has established itself as an effective medium for marginalized and poor people. Participatory communication has been defined as "A social process in which groups with common interests jointly construct a message oriented toward the improvement of their living conditions and the change of unjust social structures (Mody, 1991)". Participation of the targeted population in their own development has seen very important to make the development long lasting. The government authority can take initiatives for the developmental work but sustaining this development over a long period of time cannot be achieved without participation of the grass root people in the decisions concerning them. Yvonne (2010) argued that modern democracy requires active roles from the population and participation from members of the community. Community radio provides a platform for the rural community to express their opinions and ideas and help them to share their wisdom which enables them to solve their own problems.

"The beauty of participatory communication is that it can adopt different forms according to need, and that no blueprint model can impose itself over the richness of views and cultural interactions (Gumucio, 2001). There is need to evolve location specific model for each segment, considering the cultural, social, traditional, economical, geographical, political and environmental issues of the people in mind. Community radio has immense potential to address these differences as it is highly location and cultural specific in terms of its ownership and operation.

\section{Community radio stations: An Indian context}

Community radio has a history of struggle of several decades all over the world to achieve its present status. Initially regarded as illegal, community radio has served the poor and marginalized masses to raise their voices against their exploitation by the business class and higher authority. Realizing the potential of community radio stations, governments of different countries all over the world, are liberating their policies to establish community radio stations as legal entities and helping them to flourish.

The movement of community radio in India has been driven by an organized effort at building collective identity among vigilant citizens across the country as a grassroots culture, embracing alternative organizational practices (Singh, 2010). Unlike other countries in Latin America, Africa, Australia, Asia, community in India introduced by the government to address the developmental needs of the poor people, however the community radio movement was started by the welfare organizations and societies. The campaign for the introduction of community radio in India started in the mid 1990s, soon after the judgement of Supreme Court of India passed in February 1995, which declared "airwaves are public property". This notion of the Indian government was passed on as an inspiration to groups across the country and community radio started with only educational (campus) radio stations under somewhat strict conditions. Anna FM is India's first campus 'community' radio that was launched on 1 February 2004, controlled by Education and Multimedia Research Centre (EMRC) and the students of Media Sciences at Anna University produce all programmes. On 16 November 2006, the government of India advised a set of new Community Radio Guidelines that allowed 
the NGOs and other civil society organizations to possess and operate community radio stations (Pavarala, Venniyoor, 2009).

Tabing (2002) stated that "Community radio gives community members access to information because it gives them access to the means of communication. The most relevant information - educational and developmental - is disseminated and exchanged. Important local issues are aired. A free market place of ideas and opinions is opened up and people are given the opportunity to express themselves socially, politically and culturally. Community radio helps to put the community members in charge of their own affairs." Community radio has narrowed down the gap between the broadcasters and the audience. The audience itself has emerged as the programmer and broadcaster of the issues concerning their life, which empowers them to solve their own issues and makes them independent.

Chapman et al., (2003) argued that 'the growth of rural radio stations reflects both the improvements in information technologies and the shifting of development paradigm toward a more participatory style of information and knowledge transfer'. Inclusion of other information and technological tools with community radio like internet and mobile phones could help in amplifying the impact of community radio in the betterment of the society.

As India being diverse in every aspect, whether it is socio-economical, cultural, geographical, or technological, community radio has a very important role to play in addressing these diversities. Community radio serves the rural poor, illiterate, marginal and most ignored section of the society. The community members empower themselves by raising their voices about the issues concerning them and search for the possible solutions to their problem collectively. Community radio has the immense power to uplift the most disadvantages section of the society and provide them access and control over their life.

\section{Factors affecting the functioning of community radio stations}

The present scenario of the community radio stations raises so many questions, the most common among them are-

What are the reasons for presence of very less number of operational community radio stations in the country?

What are the factors affecting the viable functioning of the community radio stations?

What criteria should we take to study the functioning of community radio stations?

What is the impact of community radio on our society and how to study this impact?

To answer these questions, many researchers have studied different community radio stations in various organizational, social, community related, operational and technological aspects. Impact of community radio stations has also been studied in the past. Reviewing these studies can help in better understanding of the community radio and can also help in visualizing the future of community radio. A thorough review of the existing literature on community radio has been done and different criteria have been identified to study the functioning of community radio stations. These criteria are further categorized into three major groups. These are as follows-

\section{Operational aspects of CRS}

2. Community aspects of CRS

3. Role of CRS in community 
It is not enough to study only issues related to the community radio stations to understand its functioning but it is also important to take the issues related to the community and role played by CRS in a community. These three are interrelated with each other, without taking all three aspects; it is not possible to get the complete picture of CRS functioning.

\section{Operational aspects of CRS}

It deals with the organizational and management aspects of the station. Under the operational aspects of CRS, organizational profile, programme development and broadcasting and communicator profile can be studied.

\section{Organizational profile}

Organizational profile of community radio station will help in understanding the working environment and the major management and operational issues of the station. Researchers have taken different criteria to study the organizational profile of CRS. The commitment of community radio to the community plays vital role in CRS functioning (Hardyk et al., 2005). The community radio staff should have a clear understanding about the purpose to be served through the station to be more specific and committed to their actions. In case of organizational management, it is necessary to study the various stakeholders involved in operation of the radio station (Sana et al, 2012). The equity in participation of stakeholders in the management committee and their decision making power are also very important aspects of community radio functioning. It is suggested to have inclusion of community members in the management committee to establish the community ownership, thus providing opportunity for equity in participation (Patil. 2010, 2014). Further the organizational management could be understood by studying the key roles of radio management committee, policy literacy, professional journalism training or experience and volunteer cohesion in radio station (Manyozo et al., 2012, David. 2015). Analyzing the extent of women participation, their involvement in management and their decision making ability is very important to achieve the balanced development of the community (Dunu, 2015). Identifying other ICTs to be used in community radio stations and their added benefits is also important aspect to make this communication intervention to be more effective. (Tacchi, 2005, Sullivan, 2011, James, 2013). There is need to find the different problems and challenges faced by CRS to understand the operational hurdles in CRS functioning (Liz. 2009, Sullivan, 2011, Diedong and Naaikuur, 2012, David. 2015, Negash. 2016). Studying these operational factors will help community radio stations in maintaining their operational stability at present and also in future.

\section{Programme development and broadcasting}

The government has made it mandatory that the programmes broadcasted through CRS should be of immediate relevance to the community (Policy guidelines for setting up community radio stations in India, 2006). The programme broadcasted by the community radio stations directly affects the functionality of the station in the long run. To make the CRS programmes more effective it is very critical to have clear understanding of the areas of focus of different broadcasted programmes (Negash, 2016), the methods of content resource generation (Singh. 2010), the notion of editorial independence in content development, production and management, and the cost of technology used for content production (Sarma, 2013). It is necessary to conduct audience research before preparing the programme design to fulfill the informational needs of the community 
(Chapman et al., 2003). Need based programmes are key for the success of community radio stations. Identifying and sequencing the different steps in preparing a radio programme (Nabembezi et al., n.d.), programming pattern (Nandakumar and Sridharraj. 2014), modes of presentation and content analysis of CRS programmes (Pattanshetti and Shree. 2011, Dunu. 2015, Karjigi, 2016), assessment of the message/programme effectiveness (Kumar. R, 2010, Nandakumar and Sridharraj, 2014) play key role in analysing the radio programmes from a broader perspective. It is the content and design which makes the programme interesting and has an impact on the listeners. The various archiving methods adopted, duration of storage, and storage devices used and stored telephonic interviews (Raveendran and Muhammadali, 2016) helps in maintaining the qualitative record for future use. These factors related to programming and broadcasting of $\mathrm{CR}$ programmes are indispensable to study the CRS functioning in a holistic way.

\section{Communicator profile}

The profile of staff of the community radio station is very important to study as they play active role in operation of the station. Community radio staff has to design, develop and broadcast the programmes in appropriate format to make the programmes interesting and informational to the target audience. It is necessary to study the social and communication profile of the staff as it has direct impact on the quality of the programmes developed. Various researchers have suggested different social and communication characteristics of the radio staff like social participation (Kumar, 2010, Pattanashetti and Nithya Shree, 2010, 2012, Karjigi, 2016, Naik and Manjula, 2016, Ratanparkhi et al., 2016), economic motivation, mass media exposure, job satisfaction, job stress and level of participation (Kumar. 2010), innovativeness (Kumar. R. 2010, Ratanparkhi et al., 2016), their extension contact (Kumar. R. 2010, Karjigi, 2016, Ratanparkhi et al., 2016) and cosmopoliteness (Pattanashetti and Nithya Shree, 2010, 2012, Kumar, 2010) to be studied for analyzing the functioning of CRS.

\section{Community aspects of CRS}

As community radio stations deals directly with the community affairs, the various socioeconomic, cultural, technological and psychological aspects of the community affects the functioning of the station. Some of these aspects are as follows-

\section{Listener's profile}

In previous studies, listeners of CR station are the receiving end of the information broadcasted through the station, have been characterized by being heterogeneous in many aspects. The socio-personal, economic, psychological and communication characteristics of the listeners vary, due to which the perception of the listeners about community radio and CRS programmes varies.

Listener's profile can be studied by taking into account the knowledge and understanding of the concept of a community radio (Khan., 2014), perceived thoughts of CRS use, gratifications sought by CRS Listeners, gratifications obtained by CRS Listeners, types of Information obtained (Pinnock., 2014).

To identify the informational needs of the listeners, it is necessary to study understanding of the listeners regarding various developmental issues broadcasted through CRS (Das, n.d.) and their awareness and preference of the community radio 
programmes (Ratanparkhi et al., 2016). While studying their socio-personal, psychological and communication profile their cosmopoliteness, extension contact, social participation and extension participation, mass media possession, perception about CRS programmes, (Kumar, 2010, Pattanashetti and Nithya Shree, 2010, 2012, Karjigi, 2016, Naik and Manjula, 2016, Ratanparkhi et al., 2016), listening behavior, pattern of listening and time spent in listening to the programmes by listeners (Pattanshetti and Shree. 2010, Fortune and Chungong, 2013, Ratanparkhi et al., 2016), most favorite programmes and participation in mass media (Balan and Norman. 2012) and finally the constraints perceived by listeners in regard to the functioning of the $\mathrm{CR}$ and their suggestion (Karjigi, 2016, Naik and Manjula. 2016).

The programmes broadcasted through community radio station can be accordingly designed and developed by proper study of the listener's profile.

Without knowing the audience it is not possible to serve them fully. It becomes necessary to study these characteristics of the listeners to identify the informational needs of the listeners and to design and develop the community radio programmes accordingly.

\section{Community participation}

Community participation in every step is mandatory, as stated in the 2006 policy at least $50 \%$ of content shall be generated with the participation of the local community, for which the station has been set up (Policy guidelines for setting up community radio stations in India, 2006) (Fig. 1).

The different criteria studied by different researchers are volunteerism and extent of community participation in operation of CRS (Wong, 2002, Singh. 2010), extent of participation of respondents in production and broadcasting of CRS programmes (Karjigi, 2016), professional journalism training or experience of the community member (Patil. 2014) to study their participation in CRS functioning.

\section{Role of CRS in community}

The contribution made by $\mathrm{CR}$ to improve the living conditions of the community has major effects on the participation of the community and sustainability of CRS. The roles played by $\mathrm{CR}$ in life of local people are as follows-

\section{Informational role}

It is not only the farming community which has to be developed by harnessing the power of the community radio stations, it is the whole community consisting of every age group despite of their differences in socioeconomic and political background.

The various identified informational roles in previous studies are extent of dissemination of location specific information (Mannar, 2014), use of broadcasting as an educational tool and impact of radio programs on education among the respondents (Ravindranath and Thomas, 2013), promotion of traditional culture, communication and information sharing ability, entertainment and income promotion CRS programmes (Alhassan et. al 2011), informing opinions, raising awareness, and promotion of solution of problems in society (King, 2015).

Being a community media, community radio can fulfill the information needs of these different segments of the society on various issues, which makes it necessary to study the information roles played by community radio in a specific community to assess its functioning (Table 1). 
Table.1 Factors contributing to the CRS functioning

\begin{tabular}{|c|c|c|c|}
\hline \multirow[t]{3}{*}{1} & \multirow[t]{3}{*}{$\begin{array}{l}\text { Operational } \\
\text { aspects of CRS }\end{array}$} & $\begin{array}{l}\text { Organizational } \\
\text { profile }\end{array}$ & $\begin{array}{l}\text { Commitment of CR to Community, importance of management committees in the functioning of the community radios, } \\
\text { key roles of the radio management committees, influence of ICTs on the operations of the management committees, } \\
\text { community ownership of CRS, and equity in participation and avenues provided, extent of women participation, } \\
\text { involvement of women in the management and decision making of the station, various stakeholders involved \& } \\
\text { broadcasters' funding system and financial management, policy literacy, professional journalism training or experience, } \\
\text { volunteer cohesion, problems \& challenges faced by CRS, sustainability of community radio- Financial, social \& } \\
\text { institutional sustainability, best management practices followed in CRS. }\end{array}$ \\
\hline & & $\begin{array}{l}\text { Programme } \\
\text { development } \\
\text { \& broadcasting }\end{array}$ & $\begin{array}{l}\text { Areas of focus, methods of resource generation, editorial independence and content development and production \& } \\
\text { management, technology used \& costs of technology, programming pattern, programmes planned and broadcasted, steps } \\
\text { in conducting a radio programme, modes of presentation, programme design and audience research, archiving methods } \\
\text { adopted, duration of storage, and storage devices used \& telephonic interviews, message/programme effectiveness and } \\
\text { content analysis of CRS. }\end{array}$ \\
\hline & & $\begin{array}{l}\text { Communicator } \\
\text { profile }\end{array}$ & $\begin{array}{l}\text { Social participation, economic motivation, mass media exposure, job satisfaction, job stress and level of participation, } \\
\text { innovativeness, extension contact) and cosmopoliteness. }\end{array}$ \\
\hline \multirow[t]{2}{*}{2} & \multirow[t]{2}{*}{$\begin{array}{l}\text { Community } \\
\text { aspects of CRS }\end{array}$} & $\begin{array}{l}\text { Listener's } \\
\text { profile }\end{array}$ & $\begin{array}{l}\text { Knowledge of listeners about the existence of a community radio, understanding of the concept of a community radio, } \\
\text { perceived thoughts of CRS use, gratifications sought by CRS Listeners, gratifications obtained by CRS Listeners, Types } \\
\text { of Information obtained, understanding of the various developmental issues broadcasted, listening behavior, where the } \\
\text { respondents listen to radio, most favorite programmes, awareness and preference of the listeners regarding community } \\
\text { radio programmes, pattern of listening and time spent in listening to the programmes by listeners, social participation, } \\
\text { cosmopoliteness, extension contact, extension participation, mass media possession and perception about CRS } \\
\text { programmes, constraints perceived by listeners in regard to the functioning of the CR, participation in mass media, } \\
\text { problem faced by listeners and suggestion. }\end{array}$ \\
\hline & & $\begin{array}{l}\text { Community } \\
\text { Participation }\end{array}$ & $\begin{array}{l}\text { Volunteerism \& extent of community participation in operation of CRS, extent of participation of respondents in } \\
\text { production \& broadcasting of CRS programmes. }\end{array}$ \\
\hline \multirow[t]{2}{*}{3} & \multirow[t]{2}{*}{$\begin{array}{l}\text { Role of CRS in } \\
\text { community }\end{array}$} & $\begin{array}{l}\text { Informational } \\
\text { role }\end{array}$ & $\begin{array}{l}\text { Dissemination of location specific information, use of broadcasting as an educational tool \& impact of radio programs on } \\
\text { education among the respondents, promotion of traditional culture, communication and information sharing, } \\
\text { entertainment and income promotion, informing opinions, raising awareness, and promotion of criticism of problems in } \\
\text { society and awareness of political solutions. }\end{array}$ \\
\hline & & $\begin{array}{l}\text { Developmental } \\
\text { role }\end{array}$ & $\begin{array}{l}\text { Services and products of community radio, role of community radio in community development, addressing grass root } \\
\text { issues and indigenous ideas transformed into radio programs, extent of the changes in life of ordinary people, role of } \\
\text { CRS in amplifying the voices of marginal groups, empowerment of women \& CRS's effects on the lives of women, } \\
\text { local successful social initiatives of community radio station, contribution of local dialect radio programmes to the social } \\
\text { integration and rural development, livelihood improvement, decentralization and local governance, income through } \\
\text { increased economic activity, social cohesion, radio listeners groups, community mobilization, training, technical support, } \\
\text { challenges \& criticisms. }\end{array}$ \\
\hline
\end{tabular}


Fig.1 Different aspects of functioning of community radio stations

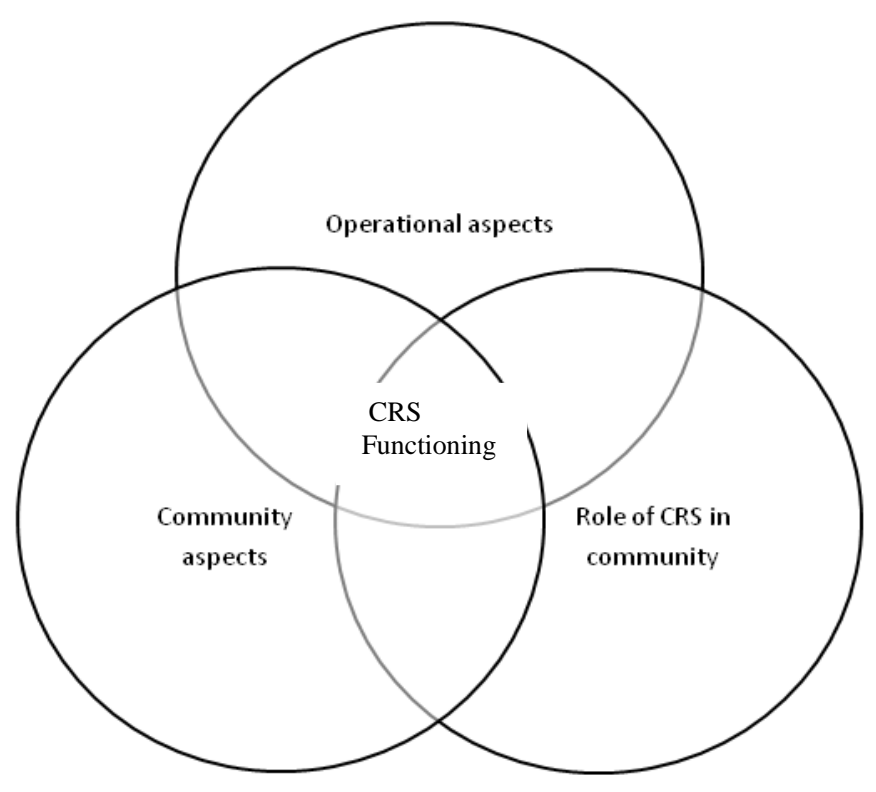

\section{Developmental role}

Development of the community as a whole is the sole purpose of the community radio stations, which makes it necessary to study the development roles played by the station in the life of the community. Some of the developmental role of community radio stations identified by different researchers are services and products provided by community radio to the community (Ngcezula, 2008), efforts of community radio to address the grass root issues and transformation of indigenous ideas into radio programs (Saini, 2015), extent of the changes in life of ordinary people (Ngugi, 2015), contribution of CRS in amplifying the voices of marginal groups (Patil, 2014), positive effects and empowerment of women through community radio programmes (Nirmala, 2015), local successful social initiatives of community radio station (Liz, 2009), contribution of local dialect radio programmes to the social integration and rural development (Anyadike et. al, 2015), livelihood improvement, decentralization and local governance, income through increased economic activity, social cohesion (Al-hassan et. al, 2011), radio listeners groups, community mobilization, training, technical support (Patil, 2010), challenges and criticisms (Liz, 2009, Alhassan et. al, 2011).

These developmental roles can create a benchmark for assessing the effectiveness of the community radio stations in fulfilling the developmental needs of the people.

In conclusion, participatory communication as being developmental tool especially in developing countries has provided opportunities for the marginalized unheard voices. Harnessing the power of participatory communication, community media are serving for the betterment of the poor people. The future of India depends upon how effectively and efficiently the community media are being utilized to address the specific informational and developmental needs of every section of the society. Community radio in this regard has proved to be very effective medium. The growth of 
community radio all over the world can be seen as slow and steady, as it took over seven decades to achieve its present status, but it has affected the lives of poor and marginalized people in so many ways.

Community radio is the medium of the poorest of the poor and also it is medium of the future. As it is not operated by few individuals of the society but has the ability to represent all weaker and marginalized section. It has the potential to bring the communities and the policy makers to a common platform for sharing the developmental needs and strategies. The government and the communities have very high expectations from this medium of communication. The present status of community radio is not up to the expectation even after a decade, it is reflected by the mere number of the operational community radio stations in the country. To understand the reasons behind the existing situation, it is necessary to deeply study all aspects of community radio stations. The studies conducted so far are mainly focused on specific aspects of community radio stations, but it is necessary to combine all these aspects for developing deep understanding about the functioning of the stations. The developed criteria in this paper can be utilized as a guide to frame the study of functioning of community radio stations and will be useful in identifying the obstacles, which a community radio station faces and help in removing them to ensure CRS's proper functioning.

\section{References}

Al-hassan, S., Andani , A, and Malik, A.A. 2011. The Role of Community Radio in Livelihood Improvement: The Case of Simli Radio. Field Actions Science Reports, The journal of field actions. 5, pp, 1-6.

Anyadike, D. O., Olemadi, N and Odoemelam, C.C. 2015. Local Dialect Radio
Programmes, Rural Development and Social Integration: The Case of Nsukka Alua, Radio Nigeria, Enugu Programme. Mediterranean Journal of Social Sciences. 6(4): 83-92.

Arora, V., Ramakrishnan, N and Fernandez, L. 2015. Community Radio and Sustainability A Participatory Research Initiative. Ideosync Media Combine in association with CEMCA and UNESCO. Retrieved from http://unesdoc.unesco.org/images/0023/ 002330/233084e. pdf on March, 2, 2017.

Balan, K. C. S and Norman, S. J. 2012. Future Tool for Rural Women DevelopmentRole of Community Radio (CR): A Study. European Journal of Applied Sciences 4 (5): 225-231.

Buckley, S. 2011. Community media: A good practice handbook. p 7. France. UNESCO.

Burns, D Heywood, F., Taylor, M., Wilde, P and Wilson, M. 2004. Making community participation meaningful: A handbook for development and assessment. Retrieved from https://www.jrf.org.uk/sites/default/files /jrf/migrated/files/jr163-communityparticipation-development.pdf on January 7, 2017.

Chapman, R., Blench, R., Kranjac-Berisavljevic $\mathrm{G}$ and Zakariah A.B.T. 2003. Rural radio in Agricultural Extension: The Examples of Vernacular Radio Programmes on Soil and Water Conservatio in Northern Ghana. Agricultural Research and Extension Network Paper No. 127. Overseas Development Institute (ODI), London, UK.

Das, S (n.d.). Analysis Of Programs Based On Developmental Issues - Case Study Of Five Community Radio Stations In Bangalore.

David, D.W. 2015. The learning curve: Distinctive opportunities and challenges posed by university-based community radio stations. Radio Journal: 
International Studies in Broadcast and Audio Media. 11(2): 88-104.

Diedong, A. L and Naaikuur, L. 2012. Ghana's experience in participatory community radio Broadcasting. Global Media Journal African Edition. 6 (2): 123-146.

Dunu, I.V. 2015. Women participation in community radio in Nigeria: towards Marginalization or exclusion? Analysis of selected campus Community radio stations. European Scientific Journal. 11(20): 180-193.

Fortune, F and Chungong, C. 2013. Community Radio, Gender and ICTs in West Africa: A Comparative

Study of Women's Participation in Community Radio Through Mobile Phone Technologies. Pp: 71-96. Rterived from https://carleton.ca/africanstudies/wpcontent/uploads /6-Nokoko-3Community-Radio-Gender-and-ICTsin-West-Africa.pdf on February, 4, 2017.

Gumucio, D. 2001. Making waves: Stories of Participatory Communication for Social Change. A Report to the Rockefeller Foundation. New York. Rockefeller Foundation

Hardyk, B., Loges, W.E and Rokeach, S.J. 2005. Radio as a Successful Local Storyteller in Los Angeles: A Case Study of KKBT and KPCC. Journal of Radio Studies 12(1), 2005, pp. 156-181.

James, S. 2013. Community Radio and Frontline SMS: Solving Rural Farmers' Challenges. EFITA-WCCA-CIGR Conference "Sustainable Agriculture through ICT Innovation", Turin, Italy, 24-27 June. Retrieved from http://www.cigr.org/Proceedings/upload s/2013/0017.pdf on February, 4, 2017.

Karjigi, K. D. 2016. Empowerment of rural households through community radio stations: An analytical study. Unpublished M.Sc. thesis, Indian Agricultural Research Institue, New Delhi.

Khan, M. 2014. Empowering locales: Need for an effective community media. Indian Journal of Public Administration. LX(1): 156-166.

King, G. 2015. Hearing community radio listeners: A storytelling approach for community media audience research. Participations: Journal of Audience and Reception studies. 12(2): 122-146.

Kumar, R. 2010. Impact of community radio station 'Namma Dhwani' on people's socio-economic and cultural developmental in Budikote, Karnataka. Unpublished M.Sc. thesis, Indian Agricultural Research Institue, New Delhi.

Liz , M.A. 2009. Kothmale Community Radio Interorg Project: True Community Radio or Feel-Good Propaganda? (doc). Retrieved from http://www.irrodl.org/index.php/irrodl/a rticle/ view/555/1160 on March, 14, 2017.

Mannar, I.S. 2014. Communicating Climate Change Using Community Radios. J ournal of Biodivers Biopros Dev 1: 114. doi:10.4172/2376-0214.1000114

Manyozo, L., Linda, G.N and Lopes, C. 2012. Models of and approaches to the station management of six African community radio broadcasters. Journal of media and communication research. Pp: 7-27.

Mody, B. (1991). Designing messages for development communication: An audience participation-based approach. New Delhi: Sage.

Nabembezi, D., Nabunya, H., Abaliwano, J and Ddamulira, D. Harnessing the Power of Community Radio Broadcasting to Promote Accountability, Transparency and Responsiveness of Water, Sanitation and Hygiene Service Provision in Uganda

Naik, V.S and Manjula, N. 2016. KCRS listeners preference towards agricultural programmes aired in radio and suggestions to improve the programme broadcasting. Agricultural Update, 11(4): 406-410.

Nandakumar, S and Sridharraj, G. 2014. 
Community Participation and its Effectiveness in The Creation of Programming/ Content by Community Radios in Kongu Region. Indian Journal of Applied Research. 4(8): 330-335.

Negash, S. 2016. Role of Community Radio in Development: A Case Study on Sangham Radio, India. Asian Mirror International Journal of Research. III(IV): 5-13.

Ngcezula. 2008. Developing a business model for a community radio station in Port Elizabeth: A case study. Retrieved from https://www.google.co.in/url?sa=t\&rct= $\mathrm{j} \& \mathrm{q}=\&$ esrc $=$ s\&source $=$ web $\& \mathrm{~cd}=2 \& \mathrm{cad}$ $=$ rja\&uact $=8 \&$ ved $=0$ ahUKEwimu $8 X S j$ L_UAhVBvI8KHfIuA4kQFggnMAE\& url=http $\% 3 \mathrm{~A} \% 2 \mathrm{~F} \% 2 \mathrm{Fcontentpro.seals.a}$ c.za\%2Fiii\%2Fcpro\%2Fapp\%3Fid\%3D 2606684872695045\%26itemId\%3D100 $9595 \% 26$ lang\%3Deng\%26service\%3Db lob\%26suite\%3Ddef\&usg=AFQjCNEx p0HhmSSeSHQhxfnXIIeqWkp7dQ\&sig 2=kavk7OR_zqzM3MU7vFUrTQ.

Ngugi, P. K. 2015. Using Community Radios as a Tool for Development. Mass Communication and Journalism. 5(6). doi:10.4172/2165-7912.1000263

Nirmala, Y. 2015. The role of community radio in empowering women in India. Media Asia, 42:1-2, 41-46, DOI: 10.1080/01296612.2015.1072335.

Patil, D. A. 2010. A Voice for the Voiceless: The Role of Community Radio in the Development of the Rural Poor. International Journal of Rural Studies. 17(1).

Patil, D.A. 2014. Exploring the Subaltern Voices: A Study of Community Radio Reporters (CRR's) in Rural India. The Qualitative Report, 19(33), 1-26. Retrieved from http://nsuworks.nova.edu/tqr/vol19/iss3 3/1 on March, 2, 2017.

Pattanshetti , M and Nitya Shree, D.A. 2010. Listening Behavior of KCRS (Krishhi Community Radio Station) Listeners. Journal of Global Communication. 3(2): $5-61$.
Pattanashetti, M and Nithya Shree,D.A. 2012. Awareness and preference of Krishi community radio programmes. Karnataka Journal of Agricultural Sciences. 25 (4) :514-519.

Pavarala Vinod and Venniyoor Sajan. ( 2009) Community Radio in India: A Brief History and Current Policy Update on community radio stations in India. Retrieved from http://mail.sarai.net/pipermail/crindia/att achments/20090206/2010e2cd/attachme nt.html $7 / 02 / 17$ www.communicationforsocialchange.or $\mathrm{g}$

Pinnock, W. J. A. 2014. "Your information station": A Case study of rural radio in the $21^{\text {st }}$ Century. Dissertations and Theses. Paper 2115. Retrieved from http://pdxscholar.library.pdx. edu/cgi/viewcontent.cgi $?$ article $=3115 \&$ context=open_access_etds on February, 4, 2017.

Policy Guidelines for Setting Up Community Radio Stations in India, 2006. Retrieved from http://www.caluniv.ac.in/globalmdiajournal/DOCOUMENTjune2010/POLI CY\%20 GUIDELINES.pdf on February $5,2017$.

Ratanparkhi, $\quad$ H.H., $\quad$ Umesh,R., Chinchmalatpure,.T and Katole. 2016. Listening Behavior of Sadhana Community Radio beneficiary farmers. Journal of Global Communication. Pp: 100-109.

Raveendran , R and Muhammadali, N. 2016. Digital Audio Archiving in Community Radios of Kerala. IOSR Journal Of Humanities And Social Science (IOSRJHSS) .21(7) Ver. VII PP 43-49.

Ravindranath , S and Thomas, J. 2013. Community Radios as a Tool for Bridging the Gap in Education: An Exploration. International Journal of Scientific Research. 2(4):171-172.

Sana, S.S.,Sanz, Z.L.M and Mass, M.P. 2012. Operation and social participation in a radio local model. Oliveira, M.; Portela, 
P. and Santos, L..A. (eds.) 2011. ECREA Radio Research Section Congress: 'Radio Evolution: technology, contents, audiences' September, 14-16, 2011, Braga, University of Minho: Communication and Society Research Centre

Saini, R. 2015. CR as a participatory grassroot communication tool : A case study Of Alfaz-E-Mewat Community Radio Station. Indian Streams Research Journal. 5(6): 1-4.

Sarma. 2013. Community Radio In India Issues And Challenges. Asian Journal of Research In Business Economics And Management. 3(1).

Singh, A.R. Community participation on campus radio: A case study of Vivek High School 90.4 FM. Invited Article. p:1-19.

Sullivan, B. 2011. The new age of radio : How ICTs are changing rural radio in Africa, African Farm Radio Research Initiative. McKay, B., Hampson, K., Perkins, K., Leclair, M and Cuddeford, V. (Eds.). Farm Radio International. Retrieved from http://bit.ly/farmradioict on March, 2, 2017.

Tabing, L. 2002. How to do Community Radio: A Primer for Community Radio Operators. New Delhi. UNESCO
Tacchi, Jo. 2005. Radio and New Media Technologies: Making Technological Change Socially Effective and Culturally Empowering. In Healy, Sianan and Berryman, Bruce and Goodman, David, Eds. Proceedings Radio in the World: Radio Conference, pages pp. 342-353, Melbourne, Australia.

Wong, A. 2002. Community Radio, Operational Structures, and PAR Methodology: A Case Study. Retrieved from http://www.ncra.ca/documents/wong2002-radio-structures-par.pdf on February, 4, 2017.

Yelvattimath , G and Nithyashree, D.A. 2014. Planning and broadcasting of programmes on health and environment and listing of suggestions of the listeners for improvement of the programmes @ KCRS. Agriculture Update. 9(2): 193-196.

Yvonne, M. 2010. Public participation for sustainable development in local cities. Moseti, Public Participation for Sustainable Development in Local Cities, 46th ISOCARP Congress 2010, Kenya.

http://www.isocarp.net/Data/case_studie s/1767.pdf

\section{How to cite this article:}

Neha Arya and Kashyap, S.K. 2019. An analysis of the Factors Affecting the Functioning of the Community Radio Stations: A Review Paper. Int.J.Curr.Microbiol.App.Sci. 8(03): 705-716. doi: https://doi.org/10.20546/ijcmas.2019.803.087 